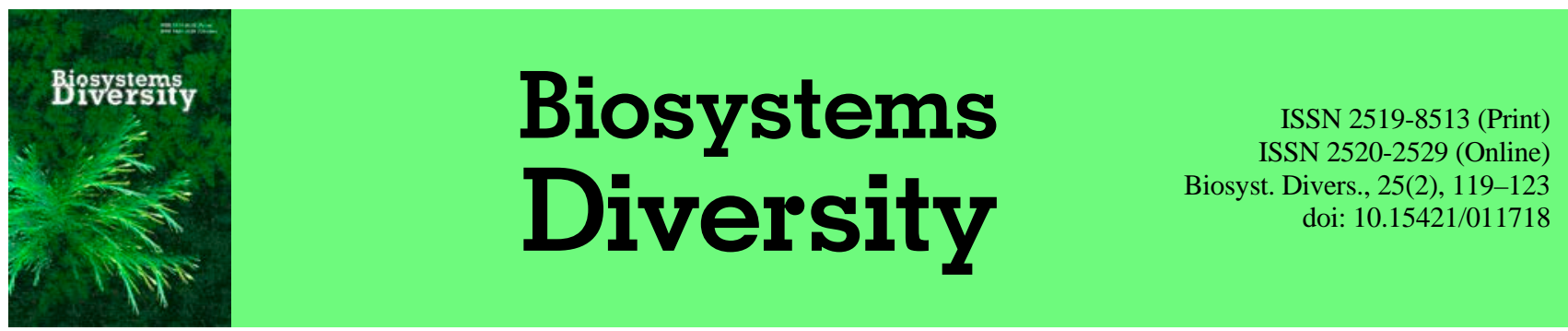

\title{
Chemical composition of essential oil and antimicrobial properties of Chrysantemum coronarium (Asteraceae)
}

\author{
I. V. Ivashchenko \\ Zhytomyr National Agroecological University, Zhytomyr, Ukraine
}

Article info

Received 21.02.2017

Received in revised form 28.03.2017

Accepted 31.03.2017

Zhytomyr National

Agroecological University, Stary Boulevard, 7,

Zhytomyr, 10002, Ukraine.

Tel.: +38-096-467-32-80.

E-mail: kalateja@ukr.net

\begin{abstract}
Ivashchenko, I. V. (2017). Chemical composition of essential oil and antimicrobial properties of Chrysantemum coronarium (Asteraceae). Biosystems Diversity, 25(2), 119-123. doi:10.15421/011718
\end{abstract}

Garland chrysanthemum (Chrysanthemum coronarium L.), or edible chrysanthemum, is a valuable food, medicinal, decorative plant, containing a considerable amount of biologically active substances. The herb is widely used as a dietary food in South-East Asia, whereas in spite of being spread throughout Ukraine, it is known there rather as a decorative than a vegetable plant. Introductory studies of $C$. coronarium were conducted on experimental plots at the Botanical Gardens of Zhytomyr National Agroecological University, which is located in Ukrainian Polesia. Chromatographic analysis of the essential oil composition was performed on the gas-liquid chromatographer Agilent Technologies 6890 with mass spectrometric detector 5973. The material for chromatographic studies was represented by $C$. coronarium inflorescences. The antimicrobial properties of the ethanolic extract from the areal parts of C. coronarium were studied on test-cultures, collected from the Ukrainian Collection of Microorganisms (UCM, Institute of Microbiology and Virology of NAS Ukraine), the test-cultures being: Escherichia coli UCM B-906 (ATCC 25922), Staphilococcus aureus UCM B-904 (ATCC 25923), Pseudomonas aeruginosa UCM B-900 (ATCC 9027), Candida albicans UCM Y-1918 (ATCC 885-653). The antimicrobial effect of the investigated substances was studied by the method of serial successive dilutions which determined minimal inhibitory concentration (MIC) and minimal bactericidal concentration (MBC). This article shows the results of chromatographic analysis of essential oil obtained from $C$. coronarium inflorescences and focuses on antimicrobial activity of the herb against the test cultures of the following microorganisms: E. coli, S. aureus, P. aeruginosa, C. albicans. In the essential oil 26 compounds have been determined, 23 of which have been identified, the major components being: chrysanthemyl acetate (24.4\%), chrysanthemol (21.8\%), chrysanthenyl acetate (7.6\%), camphor (7.3\%), $\beta$-farnesene (5.9\%), $\alpha$-bisabolol (5.6\%). C. coronarium ethanolic extract showed antimicrobial activity against gram-positive strains of $S$. aureus. In comparison with the solvent, the minimal inhibitory concentration (MIC) and the minimal bactericidal concentration (MBC) increased 4 and 2 times, respectively. We have observed only fungistatic activity against the fungus $C$. albicans - MBC values showed a twofold increase compared with the solvent. Inhibitory, bactericidal/fungicidal properties of the extract against gram-negative strains of $E$. coli and $P$. aeruginosa have not been detected. The experimental data prove that there is a good perspective for further study and application of $C$. coronarium in pharmacy and the food industry.

Keywords: garland chrysanthemum; chromatographic analysis; extract; microorganisms; antimicrobial activity

\section{Introduction}

Garland chrysanthemum (Chrysantemum coronarium L.) is a valuable food plant, medicinal and ornamental plant, which belongs to the family Asteraceae, tribe Anthemideae. Other botanical names are Glebionis coronaria L. Cassini ex Spach, Glebionis coronaria var. discolor, Glebionis coronaria var. coronaria, Chrysanthemum roxburghii Desf., Glebionis roxburghii (Desf.) Tzvelev, Xantophtalmum coronarium (L.) P. D. Sell., Matricaria coronaria (L.) Desr. It is an annual herbaceous plant with upright highly brachiferous stems. In the conditions of Zhytomyr Polesia the plants grow up to $60-143 \mathrm{~cm}$ height in culture. The leaves are bipinnately lobed, sessile, the inflorescence is anthodium. The corolla of the disk flowers is yellow, the ray florets are yellow of a different tone, sometimes white. The fruit is achene. Garland chrysanthemum or chrysanthemum greens is widely used as a dietary food plant in China, Japan, Korea, India, the USA; it is distributed throughout Ukraine, though it is used as an ornamental plant and is not commonly known as a vegetable plant. Garland chrysanthemum has a high nutritive value, due to its balanced content of vitamins, carotene, micro- and macro-elements, simple and complex carbohydrates, protein, flavonoids, lactones (Harborne et al., 1970;
El-Masry et al., 1984; Lai et al., 2007; Cherevchenko et al., 2012; Geest et al., 2016). The plant has a high content of beta-carotene and potassium and includes essential oil (Flamini et al., 2003; Senatore et al., 2004; Sebastián et al., 2006; Basta et al., 2007; Tawaha and Hudaib, 2010; Preedy, 2016). In China, garland chrysanthemum is used for treatment of gonorrhea, syphilis, for normalization of metabolism, treatment of chronic constipation, and is given as an expectorant and stomachic medication; Japanese medicine uses it for preventing cancer, and treatment of headaches. The chrysanthemum is used for treating eye diseases, ringing in the ears, swamp fever, alcoholism, kidney stone disease, radiation sickness, cardio-vascular diseases, rheumatism, hypertension (Cherevchenko et al., 2012). Garland chrysanthemum activates the immune system (Tanaka et al., 2011), and has antioxidative (Chuda et al., 1996; Kim et al., 2011), hepatoprotective (Donia, 2014), antitumoral (Choi et al., 2007; Dokuparthi and Manikanta, 2015) insecticidal (Shonouda et al., 2008), nematocidal (Bar-Eyal et al., 2006) and antimicrobial properties (Hosni et al., 2013; Lograda et al., 2013).

Garland chrysanthemum is not cultivated in Zhytomyr Polesia, therefore it is appropriate to conduct an introductory study of this valuable and undemanding plant, especially its biochemical and antimicrobial properties with a view to its usage in the food 
industry, pharmacy, perfumery, and cosmetology. The objective of this article is to evaluate the essential oil compound and the antimicrobial properties of $C$. coronarium with a view to its introduction in Ukrainian Polesia.

\section{Material and methods}

Our introductory study of $C$. coronarium was conducted on experimental plots in the Botanical Garden of Zhytomyr National Agroecological University, which is located in Ukrainian Polesia. The output seeds were obtained from the National Botanical Garden (NBG named after M M Hryshko of the National Academy of Sciences of Ukraine. The material for chromatographic research was the inflorescences of $C$. coronarium (fresh material).

Calculation of the content of essential oils was made using the Clevenger method (Syr'e lekarstvennoe rastitel'noe..., 1988). Chromatographic analysis of essential oil components was made using a gas-liquid chromatograph Agilent Technologies 6890 with mass spectrometer 5973. The conditions of the analysis: the chromatographic column was capillary DB-5, with $0.25 \mathrm{~mm}$ diameter and $30 \mathrm{~m}$ length. The speed of the carrier-gas (helium) was $2 \mathrm{ml} / \mathrm{min}$, the temperature of the heater when injecting the samples was $250^{\circ} \mathrm{C}$. The programmed temperature of the thermostat ranged from 50 to $320^{\circ} \mathrm{C}$ with $4 \%$ min speed. For identification of components, we used the library of mass spectrums NIST05 and WILEY 2007 with total number of spectra more than 470,000 in a complex with AMDIS and NIST programmes for identification (Chernogorod and Vinogradov, 2006).

The samples for micro-biological studies were collected during their blossom stage. The extract of the above-ground part of C. coronarium was obtained by infusing air-dry material in $40 \%$ ethanol (1:5) during 7 days. The research on antimicrobial activity of the extract was conducted using microbiological cultures from the Ukrainian Collection of Microorganisms (UCM, Institute of Microbiology and Virology, National Academy of Science of Ukraine): Escherichia coli UCM B-906 (ATCC 25922), Staphylococcus aureus UCM B-904 (ATCC 25923), Pseudomonas aeruginosa UCM B-900 (ATCC 9027), Candida albicans UCM Y1918 (ATCC 885-653). These microorganisms were test strains for assessing the antimicrobial activity of medicinal preparations (Podgorsky et al., 2007).

Assessment of the antimicrobial activity of the extract on microbiological cultures was conducted according to the following method of assessing sensitivity of microorganisms to antibacterial drugs (Viznachennya chutlivosti mikroorganizmiv do antibakterialnih preparativ [The determination of sensitivity of microorganisms to antibacterial drug]. Nakaz of MOZ of Ukraine No 167. 2007).

The antimicrobal activity of the substances was studied using the method of consequent dilution which includes defining the minimum bacteriostatic (MIC) and minimum bactericidal concentration (MBC). Daily microbiological cultures were obtained from dense growth media LB (Luria-Bertani medium, Merck, Germany) (Miller, 1976).

\section{Results}

The chromatographic analysis of the essential oil from inflorescences of C. coronarium discovered 26 compounds and
23 substances were identified (Table 1, Fig. 1). The main components are chrysantemyl acetate (24.4\%), chrysantemol $(21.8 \%)$, chrysantenyl acetate $(7.6 \%)$, camphore $(7.3 \%), \beta-$ farnesene (5.9\%), $\alpha$-bisabolol (5.6\%). Among the identified compounds, the dominant are chrysantemol (21.8\%), and its ester chrysantemyl acetate (24.4\%) (Table 1). The content of essential oil in inflorescences of $C$. coronarium was $0.5 \%$ (after conversion to oven dry mass).

\section{Table 1}

Chemical compound of essential oil from $C$. coronarium (blossom phase)

\begin{tabular}{cclc}
\hline No & $\begin{array}{c}\text { Duration of } \\
\text { exposure, min }\end{array}$ & \multicolumn{1}{c}{ Component } & $\begin{array}{c}\text { Numeric content within } \\
\text { the essential oil, } \%\end{array}$ \\
\hline 1 & 7.46 & yomogi alcohol & $0.82 \pm 0.011$ \\
2 & 11.18 & linalool & $2.89 \pm 0.068$ \\
3 & 13.73 & chrysantemol & $21.83 \pm 0.048$ \\
4 & 14.10 & - & $1.15 \pm 0.035$ \\
5 & 14.63 & terpinen-4-ol & $2.53 \pm 0.024$ \\
6 & 14.77 & camphore & $7.34 \pm 0.037$ \\
7 & 15.46 & $\alpha$-terpineol & $1.03 \pm 0.035$ \\
8 & 16.26 & linalyl acetate & $0.86 \pm 0.049$ \\
9 & 17.12 & chrysantenyl acetate & $7.55 \pm 0.072$ \\
10 & 17.65 & chrysantemyl acetate & $24.40 \pm 0.196$ \\
11 & 17.78 & lavandulyl acetate & $0.66 \pm 0.042$ \\
12 & 18.11 & bornyl acetate & $0.97 \pm 0.066$ \\
13 & 19.40 & 2-hexenyl caproate & $0.48 \pm 0.018$ \\
14 & 19.87 & $\beta$-elemen & $0.57 \pm 0.073$ \\
15 & 20.69 & neryl acetate & $0.23 \pm 0.034$ \\
16 & 21.06 & $\beta$-caryophyllene & $0.31 \pm 0.029$ \\
17 & 21.49 & geranyl acetate & $0.61 \pm 0.041$ \\
18 & 21.90 & $\beta$-farnesene & $5.88 \pm 0.091$ \\
19 & 23.02 & - & $0.82 \pm 0.046$ \\
20 & 23.10 & - & $1.15 \pm 0.057$ \\
21 & 23.50 & germacrene D & $4.50 \pm 0.493$ \\
22 & 23.84 & $\alpha$-farnesene & $3.45 \pm 0.453$ \\
23 & 24.23 & biciklogermakren & $0.62 \pm 0.049$ \\
24 & 24.56 & $\beta$-seskvifelandren & $2.57 \pm 0.082$ \\
25 & 28.91 & epi- $\alpha$-cadinol & $1.21 \pm 0.052$ \\
26 & 29.39 & $\alpha$-bisabolol & $5.58 \pm 0.069$ \\
\hline
\end{tabular}

Note: “-”- unidentified components.

At the first stage of studying the antimicrobial effect of $C$. coronarium alcohol extract, we studied the bacteriostatic and bactericidal activity of the solvent $40 \%$ ethanol. Bacteriostatic activity of the solvent against all used microbiological cultures was observed only after at a concentration of $1: 2$. Bactericidal/fungicidal concentration of alcohol in the solvent of $P$. aeruginosa and $C$. albicans was the same as for the bacteriostatic concentration. None of the alcohol solutions had any bacteriostatic effect on E. coli and S. aureus.

We observed moderate antimicrobial activity of the C. coronarium extract against gram-positive strains of $S$. aureus bacteria. In the liquid culture, the extracted substances stopped the growth and reproduction of bacteria in solutions of $1: 8$ and below (Table 2, Fig. 2). We observed that microorganisms inoculated in solid growth media ceased to grow after use of $1: 2$ solution (Table 3, Fig. 3). Thus, the indicators of minimum bacteriostatic (MIC) and minimum bactericidal concentration (MBC) of the sample against $S$. aureus increased by 4 and 2 times respectively in comparison with the solvent.

\section{Table 2}

Identifying minimum bacteriostatic concentration (MIC) of C. coronarium ethanol extract against microbiological cultures

\begin{tabular}{|c|c|c|c|c|c|c|c|c|c|c|c|}
\hline \multirow[t]{2}{*}{ Microbiological culture } & \multicolumn{7}{|c|}{$\begin{array}{l}\text { Growth among the bacteria of the culture in } \\
\text { tested variants at a particular solution of sample }\end{array}$} & \multicolumn{4}{|c|}{$\begin{array}{l}\text { Growth of microorganisms } \\
\text { in culture in control variants }\end{array}$} \\
\hline & $1: 2$ & $1: 4$ & $1: 8$ & $1: 16$ & $1: 32$ & $1: 64$ & $1: 128$ & $+\mathrm{K}$ & $-\mathrm{K}$ & $\mathrm{K}_{\mathrm{c}}$ & $\mathrm{K}_{\mathrm{s}}$ \\
\hline Escherichia coli UCM B-906 & - & + & + & + & + & + & + & + & - & - & - \\
\hline Staphylococcus aureus UCM B-904 & - & - & - & + & + & + & + & + & - & - & - \\
\hline Pseudomonas aeruginosa UCM B-900 & - & + & + & + & + & + & + & + & - & - & - \\
\hline Candida albicans UCM Y-1918 & - & - & + & + & + & + & + & + & - & - & - \\
\hline
\end{tabular}

Note: “+” - growth of microorganisms in culture; “-” - absence of growth of microorganisms in culture; +K - positive control of growth of microorganisms in culture; $-\mathrm{K}$ - negative control of growth of microorganisms in culture; $\mathrm{K}_{\mathrm{m}}$ - control of media cleanliness; $\mathrm{K}_{\mathrm{s}}$-control of the sample cleanliness (in 1 : 2 solution). 


\section{Abundance}

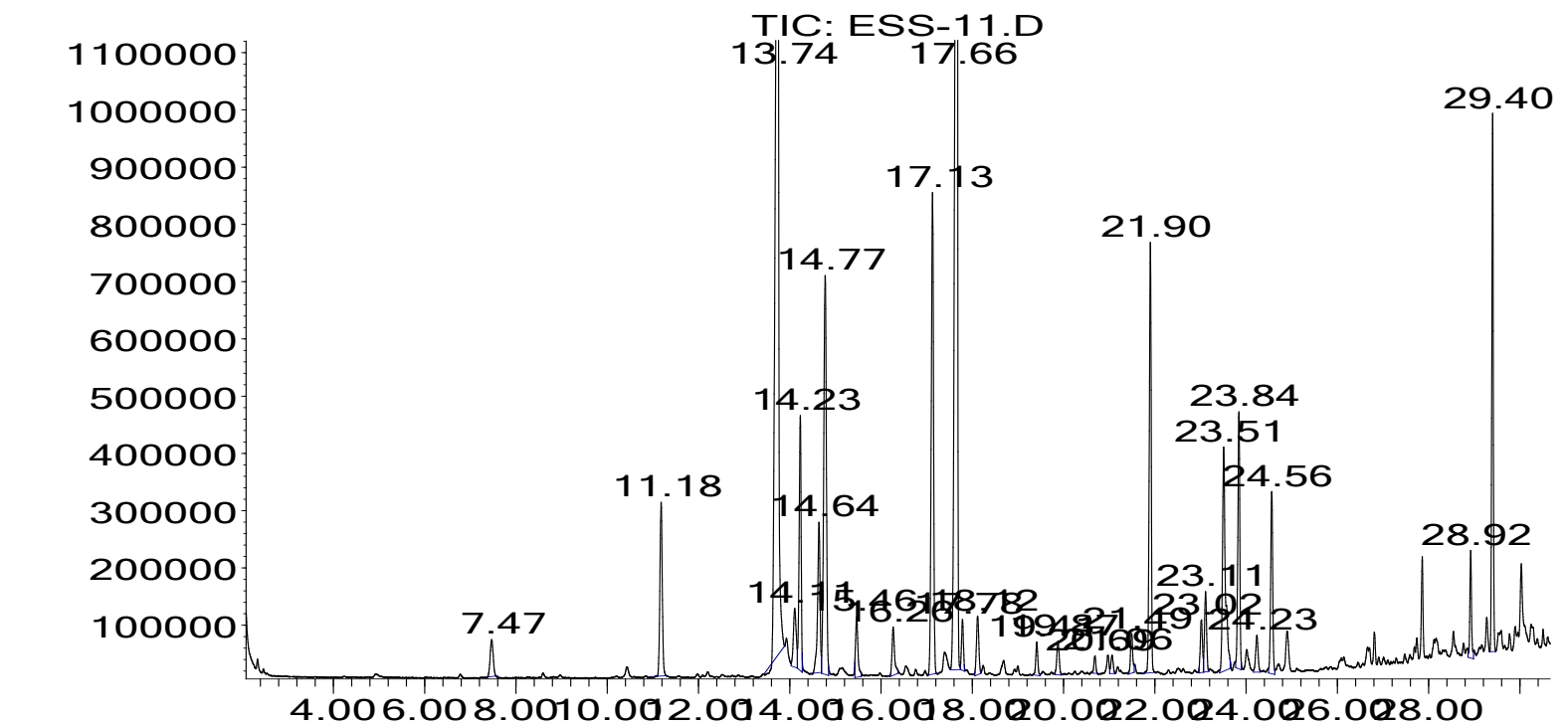

Time-->

Fig. 1. Chromatogram of essential oil of C. coronarium

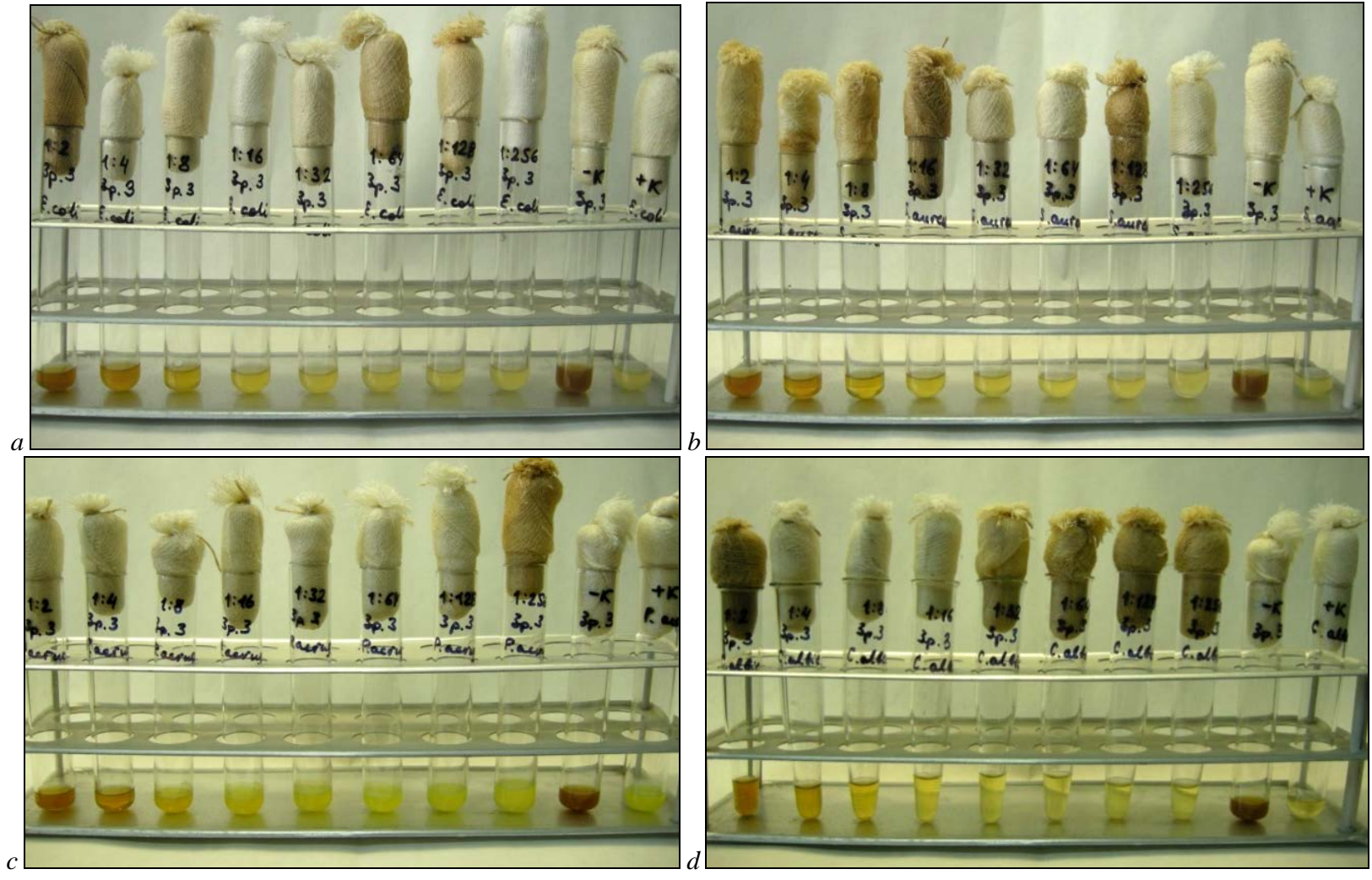

Fig. 2. Identifying minimum inhibitory concentration (MIC) of ethanol extract of C. coronarium against microbiological cultures: $a$ - Escherichia coli UCM B-906; $b$ - Staphylococcus aureus UCM B-904; c-Pseudomonas aeruginosa UCM B-900; d - Candida albicans UCM Y-1918

Table 3

Identifying minimum bactericidal/fungicidal concentration (MBC/MFC) of ethanol extract of $C$. coronarium against microbiological cultures

\begin{tabular}{lcccccccc}
\hline \multirow{2}{*}{ Tested microbiological cultures } & \multicolumn{7}{c}{ Growth among bacteria of the culture in solid media after using the corresponding diluted sample } \\
\cline { 2 - 8 } & $1: 2$ & $1: 4$ & $1: 8$ & $1: 16$ & $1: 32$ & \multicolumn{1}{c}{$1: 64$} & $1: 128$ \\
\hline Escherichia coli UCM B-906 & + & + & + & + & + & + & + \\
Staphylococcus aureus UCM B-904 & - & + & + & + & + & + & + \\
Pseudomonas aeruginosa UCM B-900 & - & + & + & + & + & + & + \\
Candida albicans UCM Y-1918 & - & + & + & + & + & + & + \\
\hline
\end{tabular}

Note: “+”- growth among the bacteria, “-”- absence of growth among the bacteria. 

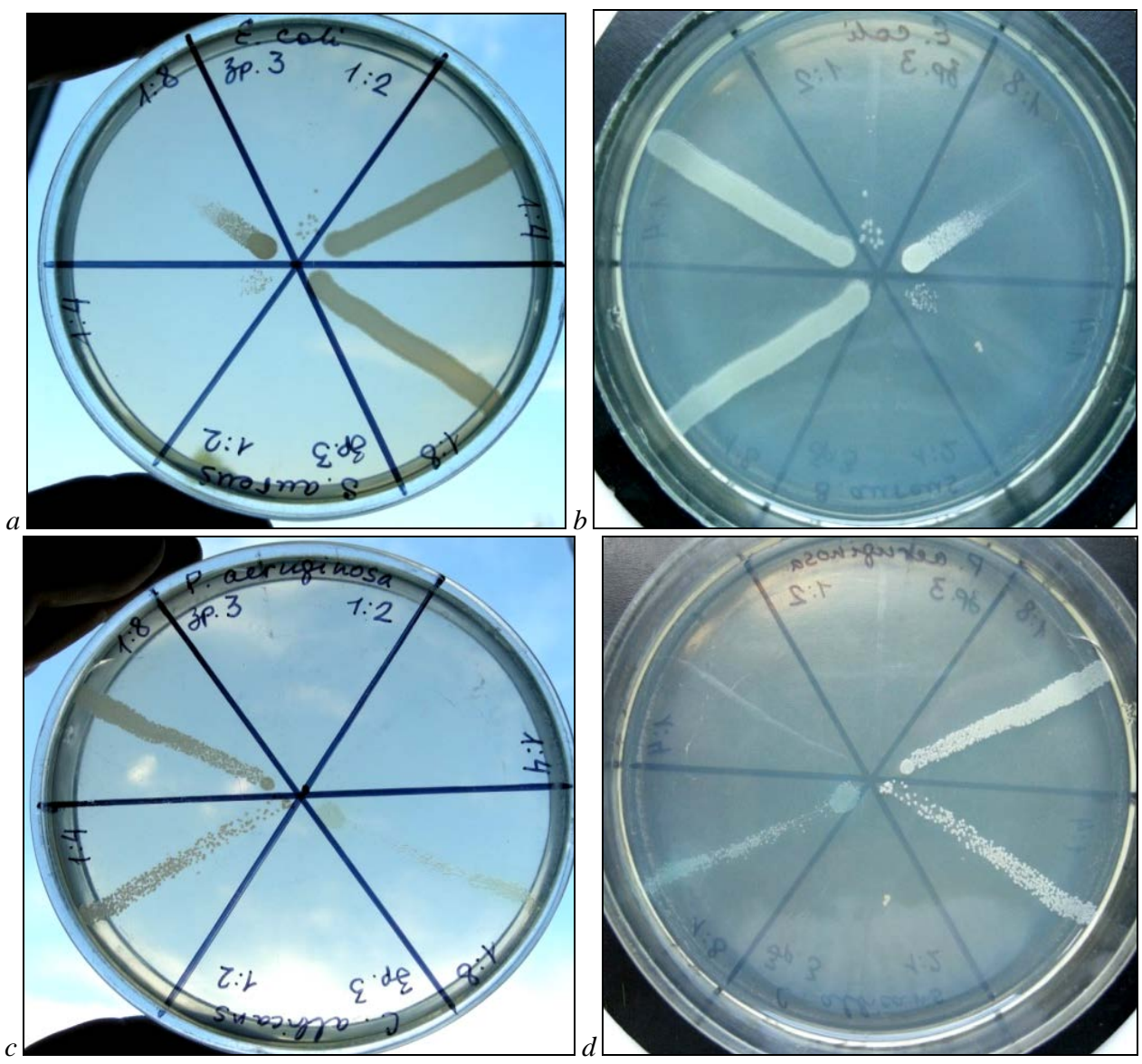

Fig. 3. Identifying the minimum bactericidal/fungicidal concentration (MBC/MFC) of ethanol extract of $C$. coronarium against tested microbiological cultures: Escherichia coli UCM B-906 and Staphylococcus aureus UCM B-904 ( $a$ - obverse, $b$ - internal view);

Pseudomonas aeruginosa UCM B-900 and Candida albicans UCM Y-1918 ( $c$ - obverse, $d$ - internal view)

Low activity of the extracted substances was also observed against the fungus $C$. albicans. The absence of growth among the microorganisms of the culture was observed in solutions $1: 4$ and lower (Table 2, Fig.2). So, the extracted substances doubled the fungicidal activity of alcohol. At the same time, the indicator of MBC sample did not differ from the similar indicator at $40 \%$ ethanol. Both cases showed absence of growth among the bacteria inoculated in solid media at the solution 1:2. The extracted substances did not increase the fungicidal activity of $40 \%$ ethanol. The increase in fungicidal activity of the solvent against the fungus C. albicans was not observed (Table 2, 3). Gram-negative bacteria $P$. aeruginosa and $E$. coli appeared to be insensitive to the substances of extract (Table 2, 3, Fig. 2, 3).

\section{Discussion}

The results of our studies concur with the data of Hosni et al. (2013), who identified 40 components of $C$. coronarium essential oil with the following dominants: cis-chrysanthenyl acetate (21.8\%), trans-chrysanthenyl acetate (12.8), (E)- $\beta$-farnesene (9.0\%), germacrene D (8.9\%) and camphor (6.0\%). We also found these compounds, but at different percentages. In essential oil extracted from samples of Garland chrysanthemum, grown in Greece, the dominant components were as follows: trans-chrysanthenyl acetate (7.8-13.2\%), cis-chrysanthenyl acetate (9.1-9.9\%), camphor (9.1-15.7\%), $\beta$-pinene oxide (7.7-8.8\%), trans-chrysanthenyl isovalerate (5.8-10.2\%) and myrcene (6.2-7.0\%) (Basta et al., 2007). Our samples contained no $\beta$-pinene oxide, trans-chrysanthenyl isovalerate and myrcene. Samples from Algeria contained no trans-chrysanthenyl acetate, and $\beta$-pinene oxide (Dokuparthi and Manikanta, 2015).

According to research by Spanish scientists, the dominant components of $C$. coronarium essential oil were: camphor (29.2\%), $\alpha$-pinene (14.8\%), $\beta$-pinene (9.5\%), liratyl acetate (9.8\%) (AlvaresCastellanos and Pascual-Vilalolos, 2003; Alvares-Castellanos et al., 2001). So, our results differ from the Spanish research data in the absence of $\alpha$-pinene, $\beta$-pinene, liratyl acetate. According to literature sources, the chemical compound of Garland chrysanthemum is variable and depends upon genetic, climatic and geographical factors (Flamini et al., 2003; Senatore et al., 2004; Sebastian et al., 2006; Hosni et al., 2013; Dokuparthi and Manikanta, 2015; Preedy, 2016).

The antimicrobial activity of extract of $C$. coronarium against S. aureus and C. albicans, which we observed, is probably related to the plant's content of essential oil and phenol compound. Our study concurs with the data obtained by Hosni et al. (2013), who established that essential oil of Garland chrysanthemum had antimicrobial properties against S. aureus, C. albicans, Salmonella typhymurium and Bacillus cereus.

\section{Conclusions}

Chromatographic analysis of essential oil extracted from inflorescences of $C$. coronarium found 26 compounds, 23 of which were identified. The dominant components were chrysantemyl acetate (24.4\%), chrysantemol (21.8\%), Chrysantenyl acetate (7.6\%), camphora (7.3\%), $\beta$-farnesene (5.9\%), $\alpha$-bisabolol (5.6\%).

We observed antimicrobial activity of alcohol extract of C. coronarium against gram-positive strains of $S$. aureus bacteria. Compared to the solvent, the indicators of minimum bacteriostatic (MIC) and minimum bactericidal concentration (MBC) increased by 4 and 2 times, respectively. Fungicidal activity was observed only against the fungus $C$. albicans - the indicators doubled compared to the solvent. We observed no bacteriostatic or bactericidal properties of the extract against gram-negative strains of $E$. coli and $P$. aeruginosa bacteria. The obtained experimental data indicate prospects of further study and usage of $C$. coronarium in pharmacy and the food industry. 
Acknowledgements. The author conveys his profound gratitude to Olexandr Bohdanovych Balko, senior research scientist at the Danylo Zabolotny Institute of Microbiology and Virology of National Academy of Sciences of Ukraine, candidate of biological sciences, for his assistance in this research.

\section{References}

Alvarez-Castellanos, P. P., \& Pascual-Villalobos, M. J. (2003). Effect of fertilizer on yield and composition of flowerhead essential oil of Chrysanthemum coronarium (Asteraceae) cultivated in Spain. Industrial Crops and Products, 17(2), 77-81.

Alvarez-Castellanos, P. P., Bishop, C. D., \& Pascual-Villalobos, M. J. (2001). Antifungal activity of the essential oil of flowerheads of garland chrysanthemum (Chrysanthemum coronarium) against agricultural pathogens. Phytochemistry, 57(1), 99-102.

Bar-Eyal, M., Sharon, E., \& Spiegel, Y. (2006). Nematicidal activity of Chrysanthemum coronarium. European Journal of Plant Pathology, 114(4), 427-433.

Basta, A., Pavlović, M., Couladis, M., \& Tzakou, O. (2007). Essential oil composition of the flowerheads of Chrysanthemum coronarium L. from Greece. Flavour and Fragrance Journal, 22(3), 197-200.

Cherevchenko, T. M., Rahmetov, D. B., \& Gaponenko, M. B. (ed.) (2012). Zberezhennja ta zbagachennja roslynnyh resursiv shljahom introdukcii', selekcii' ta biotehnologii' [Conservation and enrichment of plant resources through introduction, plant selective breeding and biotechnology]. Fitosociocentr, Kyiv (in Ukrainian).

Chernogorod, L. B., \& Vinogradov, B. A. (2006). Jefirnye masla nekotoryh vidov roda Achillea L., soderzhashhie fragranol [Essential oils of some species of the genus Achillea L., containing fragranol]. Rastitel'nye Resursy, 42(2), 61-68 (in Russian).

Choi, J. M., Lee, E. O., Lee, H. J., Kim, K. H., Ahn, K. S, Shim, B. S, Kim, N. I, Song, M. C., Baek N. I., \& Kim, S. H. (2007). Identification of campesterol from Chrysanthemum coronarium L. and its antiangiogenic activities. Phytotherapy Research, 21, 954-959.

Chuda, Y., Ono, H., Ohnishi-Kameyama, M., Nagata, T., \& Tsushida, T. (1996). Structural identification of two antioxidant quinic acid derivatives from garland (Chrysanthemum coronarium L.). Journal of Agricultural Food Chemistry, 44, 2037-2039.

Dokuparthi, S. K., \& Manikanta, P. (2015). Phytochemical and pharmacological studies on Chrysanthemum coronarium L.: A review. Journal of Drug Discovery and Therapeutics, 27, 11-16.

Donia, A. M. (2014). Biological activity of Chrysanthemum coronarium L. extracts. Annual Research and Review in Biology, 4(16), 2617-2627.

El-Masry, S., Abou-Donia, A. H. A., Darwish, F. A., Abou-Karam, M. A., Grenza, M., \& Bohlmanna, F. (1984). Sesquiterpene lactones from Chrysanthemum coronarium. Phytochemistry, 23(12), 2953-2954.

Flamini, G., Cioni, P. L., \& Morelli, I. (2003). Differences in the fragrances of pollen, leaves, and floral parts of garland (Chrysanthemum coronarium) and composition of the essential oils from flowerheads and leaves. Journal of Agricultural and Food Chemistry, 51(8), 2267-2271.

Geest, G., Choi, Y. H., Arens, P., Post, A., Liu, Y., \& Meeteren, U. (2016) Genotypic differences in metabolomic changes during storage induceddegreening of chrysanthemum disk florets. Postharvest Biology and Technology, 115, 48-59.
Harborne, J. B., Heywood, V. H., \& Saleh, N. A. M. (1970). Chemosystematics of the composiate: Flavonoid patterns in the Chrysanthemum complex of the tribe Anthemideae. Phytochemistry, 9(9), 2011-2017.

Hosni, K., Hassen, I., Sebei, H., \& Casabianca, H. (2013). Secondary metabolites from Chrysanthemum coronarium (Garland) flowerheads: Chemical composition and biological activities. Industrial Crops and Products, 44, 263-271.

Kim, J., Choi, J. N., Ku, K. M., Kang, D., Kim, J. S., Park, J. H. Y., \& Lee, C. H. (2011). A correlation between antioxidant activity and metabolite release during the blanching of Chrysanthemum coronarium L. Bioscience, Biotechnology and Biochemistry, 75(4), 674-680.

Lai, J.-P., Lim, Y. H., Su, J., Shen, H.-M., \& Ong, C. N. (2007). Identification and characterization of major flavonoids and caffeoylquinic acids in three Compositae plants by LC/DAD-APCI/MS. Journal of Chromatography B, 848(2), 215-225.

Lograda, T., Ramdani, M., Chalard, P., G. Figueredo, G., Silini, H., \& Kenoufi, M. (2013). Chemical composition, antibacterial activity and chromosome number of Algerian populations of two Chrysanthemum species. Journal of Applied Pharmaceutical Science, 3(8 Suppl 1), S6-S11.

Miller, D. (1976). Eksperimentyi v molekulyarnoy genetike [Experiments in molecular genetics]. Mir, Moscow (in Russian).

Podgorsky, V. S., Kotsoflyak, O. I., Kiprianovoy, E. A., \& Gvozdyak, O. R. (ed.) (2007). Ukrainskaya kollektsiya mikroorganizmov. Katalog kultur [Ukrainian collection of microorganisms. The catalogue of culture]. Naukova Dumka, Kyiv (in Ukrainian).

Preedy, V. R. (ed.), 2016. Essential oils in food preservation, flavor and safety. Academic Press, London.

Sebastián, B., Urzúa, A. M., \& Vines, M. (2006). Analysis of surface and volatile compounds of flower heads of introduced plants of Chrysanthemum coronarium L. growing wild in Chile. Flavour and Fragrance Journal, 21(5), 783-785.

Senatore, F., Rigano, D., De Fusco, R., \& Bruno, M. (2004). Composition of the essential oil from flowerheads of Chrysanthemum coronium L. (Asteraceae) growing wild in Southern Italy. Flavour and Fragrance Journal, 19(2), 149-152.

Shonouda, M. L., Osman, S., Salama, O., \& Ayoub, A. (2008). Insecticidal Effect of Chrysanthemum coronarium L. flowers on the pest Spodoptera littoralis Boisd and its parasitoid Microplitis rufiventris Kok. with identifying the chemical composition. Journal of Applied Sciences, 8(10), 1859-1866.

Syr'e lekarstvennoe rastitel'noe. Metody opredelenija vlazhnosti, soderzhanija zoly, jekstraktivnyh i dubil'nyh veshhestv, jefimogo masla [Medicinal plant raw material. Methods for determination of moisture, ash content, extractives, tannins, essential oil]. GOST 24027.2-80 [1981-01-01]. Moscow, 1988 (in Russian)

Tanaka, S., Koizumi, S., Masuko, K., Makiuchi, N., Aoyagi, Y., Quivy, E., Mitamura, R., Kano, T., Ohkuri, T., Wakita, D., Chamoto, K., Kitamura, H., \& Nishimura, T. (2011). Toll-like receptor-dependent IL-12 production by dendritic cells is required for activation of natural killer cell-mediated Type-1 immunity induced by Chrysanthemum coronarium L. International Immunopharmacology, 11(2), 226-232.

Tawaha, K., \& Hudaib, M. (2010). Volatile oil profiles of the aerial parts of Jordanian garland, Chrysanthemum coronarium. Pharmaceutical Biology, 48(10), 1108-1114. 